\title{
Autoria, obra e público na poesia colonial luso-brasileira atribuída a Gregório de Matos e Guerra
}

\author{
João Adolfo Hansen \\ Universidade de São Paulo
}

Resumo: O artigo trata do corpus poético colonial atribuído a Gregório de Matos e Guerra (1633-1696), especificando seus códigos linguísticos, retórico-poéticos e teológico-políticos, e códigos bibliográficos, como a manuscritura. Descreve apropriações nacionalistas do corpus feitas por críticos brasileiros românticos, deterministas e modernistas dos séculos XIX e XX, propondo a historicidade seiscentista das categorias autor, obra, público como critério crítico do anacronismo nacionalista.

Palavras-chave: Gregório de Matos e Guerra, poesia luso-brasileira seiscentista, teologia-política, gênero cômico, história literária, anacronismo.

Nas histórias literárias brasileiras, Gregório de Matos e Guerra (1633/16361696) é dado como autor de poemas líricos e satíricos publicados em vários códices manuscritos dos séculos XVII e XVIII. Impressos muitas vezes desde o século XIX, todos são apógrafos. Com letra de Gregório, só se conhece a assinatura da sua matrícula no curso de Direito Canônico da Universidade de Coimbra. Como outros poetas da Península Ibérica, nada editou em vida. O filólogo brasileiro Antônio Houaiss propôs que os poemas foram reunidos sem critério normativo por admiradores, demonstrando que, desde o século XIX, as edições se baseiam em um único códice apógrafo, permanecendo incompletas (7: 1727). Não tenho interesse em classificá-los dedutivamente, ou neokantianamente, 
com a categoria estilística "barroco," inexistente no século XVII. Para especificar a particularidade histórica dos seus sistemas de representação, proponho-os como produtos de práticas contingentes que, em seu presente, emularam referências poéticas e retóricas de durações históricas heterogêneas, diacrônicas e sincrônicas, gregas, latinas, trovadorescas, petrarquistas, quinhentistas e seiscentistas.

O primeiro compilador conhecido de poemas atribuídos a Gregório de Matos foi Manuel Pereira Rabelo, um letrado que viveu na Bahia na primeira metade do século XVIII. Rabelo afirma que coletou poemas deformados pelo tempo da boca de pessoas antigas que haviam conhecido o poeta ou possuíam folhas volantes com poemas manuscritos que lhe eram atribuídos. Sabe-se que folhas manuscritas, semelhantes aos pliegos sueltos espanhóis e aos livrets de colportage franceses, circularam na Bahia nos séculos XVII e XVIII. Caso das "loas das judengas," panfletos difamatórios publicados no sábado de Aleluia, semelhantes aos cartelli infamanti que, nesse tempo, eram afixados nas casas de Roma (Burke 50). Segundo Rabelo, o governador João de Lencastre também ordenara abrir em palácio um livro de páginas em branco para que pessoas conhecedoras de poemas de Gregório de Matos pudessem copiá-los ou ditá-los a um escrivão.

Não se sabe bem por que Rabelo fez a compilação. Não dá explicações, nem diz por que o fez na forma de miscelânea ou "papéis vários." Na Bahia já existiam antologias manuscritas de obras de poetas nascidos no Estado do Brasil e de portugueses e espanhóis dos séculos XVI e XVII. Pode-se levantar a hipótese de que tentava consolidar um costume poético local. Crendo-se no que diz, tratava de defender a memória do poeta contra detratores. A hipótese é verossímil e pode ser reforçada pelo fato de o primeiro volume da compilação ser aberto pelo texto de gênero prosopográfico, Vida do excelente poeta lírico, o doutor Gregório de Matos e Guerra. O título parece estranho, pois desloca a coletânea do campo baixo da sátira, pela qual o nome Gregório de Matos era famoso, identificado a um apelido, Boca do Inferno, para o campo da lírica que, na hierarquia então vigente dos gêneros, situava-se acima do cômico. Inventada com os lugares-comuns epidíticos de pessoa usados nos poemas compilados, a Vida funciona como protocolo de leitura deles.

Não se pode ler a Vida sem precauções. Recorrendo a lugares-comuns de pessoa do gênero do retrato encomiástico associado ao elogio, Rabelo compõe 
um éthos e ações que caracterizam Gregório como homem infame e excelente poeta. Segundo ele, o homem é infame como um scurra, ou bufão, pois tem o juízo desregrado pelo excesso do humor sanguinário, que causa seu desejo irracional de sempre fazer justiça a qualquer preço. O desconhecimento da medida racional o impede justamente de ser justo, pois seus atos desregrados não obedecem à medida dos decoros. Mas os poemas em que vitupera a corrupção têm grande engenho e arte. Homem péssimo, excelente poeta, é instrumento da Providência divina: Rabelo motiva substancialmente o nome materno do personagem, Guerra, afirmando que suas sátiras têm a eficácia de outros flagelos, a peste e a fome, com que Deus pune os pecados da Bahia. A obscenidade da sátira é "causa segunda," no sentido escolástico, instrumento da guerra divina contra o pecado. Logo, ainda as mais sórdidas obscenidades poéticas têm sentido sagrado, que deve ser testemunhado pelo destinatário.

A biografia e a compilação de Rabelo permaneceram esquecidas até 1841, quando o Cônego Januário da Cunha Barbosa, membro do Instituto Histórico e Geográfico Brasileiro, publicou dois poemas jocosos da compilação, "O músico castigado" e "O livreiro golotão," anexando-lhes uma paráfrase da Vida no Jornal do Instituto Histórico e Geográphico Brasileiro. Patrocinado pelo Imperador Pedro II, o Instituto Histórico e Geográfico Brasileiro então inventava tradições nacionais e nacionalistas. Barbosa era romântico, leu a ficção do retrato do personagem como documento da vida do homem empírico. Na paráfrase, elimina as categorias retórico-poéticas e teológico-políticas escolásticas com que Rabelo compõe e interpreta ações, eventos e palavras da vida do personagem como signos da Providência. A interpretação providencialista, típica do Antigo Estado português, é substituída por categorias românticas que definem o tempo histórico como o contínuo evolutivo kantiano-hegeliano por onde o espírito do estado nacional brasileiro progride em direção à realização de si mesmo encarnado na consciência crítica de Gregório, que o intui e prenuncia como a futura "brasilidade" romântico-nacionalista dos séculos XIX e XX. A paráfrase elimina mais coisas. Rabelo inventa o personagem com lugarescomuns que constroem seu éthos vicioso. Barbosa os interpreta como evidências documentais da psicologia e hábitos doentios de um homem empírico. Rabelo compõe seu retrato com o topos do ócio, caracterizando seu estatuto 
social superior segundo a ética aristocrática do século XVII. Barbosa interpreta o ócio aristocrático pela perspectiva da ética burguesa do trabalho, propondo que o homem foi um vadio.

A paráfrase de Barbosa foi reproduzida pelo historiador Francisco Adolfo de Varnhagen no primeiro volume de seu Florilégio da poesia brazileira, de 1850. Varnhagen edita poemas atribuídos a Gregório e dá início à censura deles usando signos gráficos que indicam supressões de palavras, versos e estrofes. Na apresentação biográfica que os precede, elimina a alusão à função providencialista da sua infâmia, substituindo-a pelo discurso médico que classifica o homem como personalidade doentia, cujas taras são causas da obscenidade da sua obra. Vadio, doente, obsceno, Gregório é, apesar disso, talvez por isso, crítico protonacionalista da dominação metropolitana, avant coureur da nacionalidade, como Euclides da Cunha ainda diria na sua correspondência com Tristão de Alencar Araripe Júnior em 1903.

Nesse momento, o dispositivo retórico inicial de atribuição de autoria está totalmente eliminado. Os pressupostos retórico-poéticos e teológico-políticos dos procedimentos de Rabelo são esquecidos e o conjunto dos manuscritos é definitivamente entendido como sendo da autoria de um homem protonacionalista, que neles expressa sua psicologia doentia. A própria concepção de auctoritas do dispositivo inicial de atribuição muda radicalmente com a eliminação dos preceitos retóricos do retrato do personagem e a substituição deles pela interpretação psicológica da vida do homem. Simultaneamente, a construção romântica do poeta por meio da psicologia do homem passa a determinar o juízo estético, privilegiando-se características expressivas, como originalidade, inexistente nas práticas de representação da Bahia do século XVII que, ordenadas por preceitos da mímesis aristotélica como emulação de autoridades dos gêneros, não conheciam a competição das obras no mercado dos bens culturais nem os direitos autorais da livre concorrência burguesa.

Em 1870, o crítico determinista Sílvio Romero, autor da primeira história da literatura brasileira, descobriu em Gregório O Brasileiro, o homem nem branco, nem negro, nem índio, "filho do país" ou mazombo, cujas sátiras teriam ridicularizado as pretensões separatistas das três raças formadoras da nacionalidade (2: 373-79). Outras interpretações dos poemas deram continuidade 
a esse modelo simultaneamente romântico, positivista, psicologista, racista e nacionalista. Nos anos 1890, o crítico e historiador literário José Veríssimo caracterizou Gregório como "nevropata" e "nervoso," acusando a falta de originalidade de poemas que são emulações ou imitações intencionais de Francisco de Quevedo e Luis de Góngora (72). Em 1893, apareceu o primeiro livro consagrado ao poeta, Gregório de Matos. Seu autor, Araripe Júnior, faz de Gregório um tarado exemplar da sua teoria determinista da obnubilação, segundo a qual o clima tropical da Bahia determina a relaxação das sinapses do homem que já tinha sido "fauno de Coimbra," causando sua dissipação moral expressa nas indecências dos poemas (42). Araripe Júnior os interpreta como expressão do pessimismo e ressentimento do mazombo colonial frente à ascensão social de negociantes plebeus enriquecidos com a máquina mercante. O pessimismo e o ressentimento da obnubilação são lugares-comuns repetidos por historiadores literários no século XX. Em 1923, Afrânio Peixoto, da Academia Brasileira de Letras, editou as obras completas atribuídas a Gregório de Matos. Não tão completas, Peixoto elimina os poemas escatológicos, mandando-os para o inferno da Biblioteca Nacional. Nos anos 1930, Sílvio Júlio afirmou que os poemas são plágios de um "negligente e obsceno tocador de viola" (103). Em 1946, o filólogo Segismundo Spina, da Universidade de São Paulo, publicou Gregório de Matos, antologia acompanhada de comentários filológicos, estilísticos e críticos. Spina lê os poemas segundo categorias retóricas, mas de uma retórica romanticamente restrita aos tropos e figuras da elocução interpretados psicologicamente.

Em 1968, James Amado e Maria da Conceição Paranhos estudaram 17 códices manuscritos, a maioria deles da Seção de Manuscritos da Biblioteca Nacional do Rio de Janeiro, e editaram o Códice Rabelo (Matos, Obras completas). Em Salvador, prepostos da ditadura militar declararam Gregório de Matos "subversivo, anticlerical e pornógrafo" e ordenaram o confisco de sete mil exemplares da edição para fazer um auto-da-fé. A intervenção de um governador o impediu. A partir dos anos 1970, membros da neovanguarda concretista de São Paulo declararam a poesia de Gregório de Matos esteticamente "revolucionária" e politicamente "antropófaga cultural," retomando a antropofagia cultural (1928), do modernista Oswald de Andrade, e o make it new de Pound. O músico Caetano Veloso musicou um soneto, "Triste Bahia," como alegoria 
do Brasil da ditadura militar. Em 1989, Haroldo de Campos, em O seqüestro do barroco na formação da literatura brasileira: o caso Gregório de Matos, criticou com nacionalismo o nacionalismo de Antonio Candido, crítico literário brasileiro, por ter excluído Gregório de Matos e "O Barroco" de Formação da literatura brasileira (1959). Esta obra data a origem da literatura brasileira e os processos ilustrados da sua Bildung romântica na poesia de árcades luso-brasileiros do século XVIII e textos românticos do século XIX, excluindo do cânone o chamado barroco como manifestação literária portuguesa assistemática. Hoje, a poesia atribuída a Gregório é pouco lida. Mas as versões românticas, positivistas, modernistas e neovanguardistas da vida do homem circulam, fazendo dele um poeta barroco protonacionalista, rebelde anarco-tropicalista, revolucionário, defensor dos direitos humanos e vanguarda de um suposto proletariado colonial.

\section{La mouvance na Bahia dos séculos XVII e XVIII}

Para especificar a historicidade dos conceitos de autor, obra e público da poesia atribuída a Gregório de Matos, relaciono seus códigos linguísticos, retórico-poéticos e teológico-políticos, com os códigos bibliográficos da manuscritura colonial. Lembro que, no século XVII, o significado de publicação tinha extensão maior que hoje: o manuscrito, que fazia circular variantes dos poemas, também era publicação, diferentemente de agora, quando se entende pelo termo publicação o texto impresso. Grande parte das letras coloniais foram inicialmente publicadas como manuscritos, tornando-se "obras" somente quando oralizadas em circunstâncias cerimoniais e polêmicas.

O recente livro de Marcello Moreira sobre os códices gregorianos demonstra exaustivamente que, na Bahia do século XVII, a oralização de poemas produzia variantes copiadas em manuscritos. Segundo a formulação de Moreira, as variantes produziam uma mouvance discursiva semelhante à tratada por Paul Zumthor em seus estudos da poesia medieval. Baseado em evidências da existência de uma cultura de escribas que faziam cópias de textos impressos e manuscritos na Bahia, Moreira critica a filologia de Lachmann e Bédier, demonstrando que seus pressupostos sobre autoria e texto (originalidade, genuinidade, autenticidade, primeira intenção autoral, restituição de texto etc.) 
são essencialmente românticos e não podem ser universalizados transistoricamente, pois não dão conta dos modos seiscentistas da invenção, comunicação e consumo da poesia. Comprova que, desde o século XIX, quando os poemas passaram a ser editados em forma impressa, eliminou-se a primeira ordenação que têm nos códices manuscritos. Neles, os poemas são dispostos segundo uma hierarquia dos gêneros que constitui um conjunto polilógico, com remissões e citações internas. O conjunto é destruído quando os poemas são publicados como obras isoladas, autonomizadas como objeto de contemplação estética, em antologias, como a de Varnhagen e as dos séculos XX e XXI. A pontuação retórica, indicativa de pausas da actio da oralização dramática deles, é substituída pela pontuação gramatical moderna, somente indicativa de funções sintáticas.

Citando Roger Chartier, Moreira propõe que o estudo de textos coloniais depende da especificação histórica e filológica das categorias de atribuição, designação e classificação dos discursos peculiares ao tempo e lugar a que pertencem. E que também se deve especificar a modelização da significação deles por seus suportes de transmissão. A compreensão deles pressupõe necessariamente o estudo das transações, sempre instáveis e renovadas, entre as obras e a pluralidade de seus estados, entendendo-se estado não como sucessão de etapas redacionais do texto-sentido dominante em crítica textual-mas como conjunção particular de códigos linguísticos e códigos bibliográficos da sua invenção, circulação e recepção. Os estados referidos por Chartier e Moreira são modalidades de inscrição dos textos cujo reconhecimento subverte o modo tradicional de lê-los, porque considera a materialidade das práticas de inscrição evidenciadas no meio propriamente bibliográfico de sua transmissão como condicionante e participante da significação. Obviamente, o manuscrito não é um objeto natural. Quando lido segundo a particularidade histórica dos seus processos materiais, elimina-se a naturalidade com que rotineiramente é entendido como suporte neutro de um texto interpretado como expressão da psicologia de um tarado, espelho refletor do real e proto-origem do nacional, evidenciando-se a existência de práticas simbólicas coloniais desconhecidas pela historiografia literária brasileira.

Na Bahia de fins do século XVII e da primeira metade do século XVIII, os códices compostos de centenas de folhas manuscritas de papel de várias 
dimensões e procedências foram o principal meio de publicação de poesia. Evidentemente, não o único. A coroa portuguesa então proíbe a imprensa, mas a cultura do impresso existe. O livro é raro, caro e censurado, mas corre paralelamente à manuscritura. Os dois sistemas interferem um no outro de modos variados. Algumas vezes, os manuscritos imitam a letra impressa de livros cujos tipos já tinham imitado a letra de manuscritos, numa circularidade que, na Europa, é observável desde a invenção da imprensa. A ordenação dos poemas por gêneros em edições impressas, que acontece desde o século XVI, principalmente, também se encontra em códices baianos, como o Códice Rabelo, ou o Códice AsensioCunha, da Biblioteca da Universidade Federal do Rio de Janeiro. Muitas vezes, o impresso estava no horizonte das práticas de escrita, compilação e transmissão de manuscritos como fornecedor de poemas copiados e acrescentados à coleção: caso de textos de poetas espanhóis como Lope de Vega, Góngora, e Quevedo, e portugueses como Francisco Manuel de Melo, Francisco Rodrigues Lobo, Violante do Céu, Tomás Pinto Brandão, lidos em edições impressas e transcritos em alguns códices sob a classificação autoral Gregório de Matos e Guerra. ${ }^{1}$ $\mathrm{O}$ nome não indicava necessariamente a autoria individualizada e detentora da propriedade autoral dos poemas, como hoje, quando o nome do autor se associa a direitos autorais regrados pelas delicadas leis capitalistas da livre concorrência; ao contrário, o nome era usado como dispositivo discursivo que classificava estilos e gêneros, e, no caso de Gregório de Matos, principalmente de uma de suas espécies, a sátira. Esses usos evidenciam que o conceito de publicação da manuscritura colonial pressupõe conceitos particulares de autor, obra e público.

Hoje, considera-se que um texto está publicado quando é impresso e circula na esfera pública, por oposição aos usos privados dele. No século XVII, os manuscritos que se destinavam a usos de particulares também eram "publicação." Publicação sempre inacabada, pois era sempre possível acrescentar mais uma página de cópia de impressos ou de transcrição do oral. Os códices circulavam de mão em mão em círculos familiares, e eram trocados entre ordens religiosas emprestados para serem copiados, etc. ${ }^{2}$ Seus usos coloniais evidenciam outro conceito de público, associado ao de publicação. Era conceito corporativo, juridicamente incluído no conceito de bem comum do pacto de sujeição da colônia à coroa portuguesa. 


\section{Público, publicação e representação na Bahia seiscentista}

Público não era, no século XVII, a esfera das iniciativas dotadas de autonomia política e crítica teoricamente garantida por direitos democráticos declarados nas constituições, mas significava a totalidade das ordens sociais que constituíam a res publica, hierarquizadas como exercício da representação da sua subordinação ao bem comum do império português. Ou seja, correspondia à esfera definida como "pública" porque era nela que se dava em representação a autoridade do poder real que fundamentava as representações do bem comum. Nelas, o conceito de público aparecia representado como a totalidade das ordens sociais do império português como corpo místico ou corpo político de vontades unificadas na subordinação do pacto de sujeição. ${ }^{3} \mathrm{O}$ bem comum era afirmado como a finalidade última da ação da totalidade jurídico-mística do corpo político integrado pacificamente em ordens e estamentos sociais subordinados, dando-se em representação nas representações particulares produzidas como teatralização corporativista ou teatro das relações pessoais onde se revelava a subordinação do próprio público para destinatários particulares. O público se constituía como testemunho subordinado da autoridade que lhe era dada em representação nas representações, diferentemente do que ocorre desde o final do século XVIII com o público das sociedades de classes modernas. Como indica Hélène Merlin: "O desdobramento da esfera pública estruturada pela representação está ligado aos atributos da pessoa: a insígnias (brasões, armas), a uma aparência (vestimentas, penteado), a uma atitude (maneira de saudar, comportamentos), a uma retórica (estilo do discurso, fórmulas em geral) —em uma palavra, a um código estrito de comportamento 'nobre"' (26). Incluídos na totalidade supostamente pacífica do bem comum, autores, ouvintes e leitores empíricos se definiam como membros subordinados que deviam reconhecer sua posição subordinada. Assim, a representação de cada texto particular e o meio material que a comunicava reproduziam a representação do que cada membro do corpo místico da colônia já era, prescrevendo, ao mesmo tempo, o que devia ser, ou seja, persuadindo-o a permanecer sendo o que já era, como Merlin demonstrou ocorrer na França (30). Os traços que definem o público colonial nos manuscritos são, por isso, semelhantes aos do público do teatro propostos por Chartier ao tratar do público francês do Ancien Régime: 
heterogêneo, mas hierarquizado pelo espetáculo que lhe era dado a ouvir e ler como encenação da sua subordinação (48).

Categorias metafísicas, teológico-políticas e retórico-poéticas modelam a representação como fundamento e mediação das representações particulares da subordinação de ordens sociais e indivíduos nos poemas do corpus atribuído a Gregório de Matos. ${ }^{4}$ Evidenciam-se, também, em mais discursos baianos na segunda metade do século XVII, como atas e cartas do Senado da Câmara de Salvador.

Representação é categoria histórica substancialista, ou a forma cultural específica da política católica portuguesa que, nesse tempo, estrutura as práticas discursivas e não discursivas da Bahia. Categoria tabular, a representação condensa articulações e referências de sistemas simbólicos anteriores e contemporâneos como cerrada unidade de metafísica, teologia, política, ética e retórica escolasticamente doutrinadas. Inventada mimeticamente por procedimentos retóricos, representação determina as representações particulares como evidentia ou efeitos da presença de princípios teológico-políticos católicos constitutivos das formas das posições sociais de estamentos e indivíduos unificados como "corpo místico" subordinado no pacto de sujeição. As representações particulares evidenciam para seus destinatários que a tipologia das formas inventadas retoricamente pela representação corresponde à topologia das posições sociais doutrinadas teológico-politicamente como representação. Nas práticas simbólicas desse tempo, a (des)constituição retórica do tipo prova a (im)propriedade política do topos.

Todas as representações mediadas pela representação são produzidas como imagens fornecidas à imaginação dos autores pela sua memória dos usos socialmente autorizados dos signos. Metafísica, a representação pressupõe que o atributo do Ser divino se aplica às coisas da natureza e aos eventos da história, tornando-os convenientes e semelhantes, e, simultaneamente, diversos e diferentes entre si. Todos são convenientes ou semelhantes pela sua ordenação em relação ao Um ou Máximo, como então se diz com Santo Tomás de Aquino, pois todos são seres criados como efeitos pela mesma Causa Primeira. Por participarem em sua Causa, todos são análogos a Ela e, em cada um deles, como análogo, a Unidade divina é posta como definição que os hierarquiza. Assim, todas as palavras que figuram os conceitos dos seres se correspondem 
pela semelhança que os liga como conceitos de seres criados pela mesma Coisa, podendo valer umas pelas outras como seus signos reflexos. Como todos os seres e todas as palavras são apenas semelhantes, ou seja, não idênticos, é possível, nas artes e nas formas de diç̧ão aguda da poesia e da prosa, produzir relações aparentemente incongruentes entre coisas e conceitos distantes. A representação figura teologemas testamentários que definem a eficácia dos conceitos representados como manifestação da luz natural da Graça inata. Assim, o meio material da linguagem é percebido, na experiência da representação, como evidentia da Presença divina. Nas artes, na prosa e na poesia, a representação satura as formas não como "barroco," conceito estético neokantiano inexistente no século XVII, mas como acúmulo compendiário que exemplifica a presença da Luz na multiplicidade das coisas e dos conceitos figurados nas formas. A representação é política, ou seja, as formas discursivas encenam posições hierárquicas do sujeito de enunciação, dos tipos representados, do destinatário e dos públicos empíricos. Sempre é posição social integrada na hierarquia, sendo definida e composta como representação testemunhada pelo destinatário e pelos públicos empíricos também constituídos como representação.

As representações particulares são sempre mediadas pelas categorias metafísicas, dialéticas e retóricas que constituem a representação: presença da unidade indeterminada de Deus (nas coisas, conceitos e signos); analogia (das coisas, conceitos e signos com a substância metafísica de Deus); semelhança/ diferença (das coisas, conceitos e signos como entes participantes por atribuição e proporção na mesma Causa como efeitos criados e signos reflexos); atos da predicação do juízo (evidenciando a presença do conselho da luz da Graça inata). ${ }^{5}$ A forma do $e u$ da enunciação e dos destinatários não é psicologicamente expressiva, como a da subjetividade moderna contraditoriamente dividida pela classe na livre concorrência burguesa, mas retórica, inventada pela aplicação de fórmulas adequadas como figuração de paixões e caracteres de tipos hierarquizados. As formas efetuadas são substancialistas e demonstram o que é afirmado na doutrina escolástica contemporânea: o desenho-fantasma, ideia, conceito, imagem mental-que os homens fazem das matérias a que aplicam o pensamento evidencia a participação análoga ou proporcionada da sua alma na substância metafísica de Deus, quando é figurada nas representações 
teológico-políticas da doutrina católica do poder. A doutrina reitera, contra Maquiavel e Lutero, que as leis positivas existentes são legítimas porque expressam a lei natural da Graça que reflete a lei eterna de Deus. Assim determinadas, as refrações da representação na Bahia do século XVII põem em cena os direcionamentos particulares e polêmicos do sentido das práticas locais, sendo ativamente constitutivas da sua realidade.

\section{Auctoritas e dispositio dos poemas}

Há 15 códices da poesia atribuída a Gregório de Matos na Biblioteca Nacional do Rio de Janeiro, um na Biblioteca do Itamarati (Códice Varnhagen), outro no Instituto de Estudos Brasileiros da Universidade de São Paulo e pelo menos uma dezena deles em coleções particulares, além dos muitos de bibliotecas portuguesas. Em Washington, D.C., a Biblioteca do Congresso tem um códice datado de 1711, cuja capa foi utilizada como frontispício da edição de Amado (Matos, Obras completas). Essa edição reproduz o Códice Rabelo, sendo particularmente valiosa porque reproduz, antes de cada poema, no alto da página, didascálias que informam sobre temas, circunstâncias da invenção, pessoas referidas e modos da circulação deles. Por exemplo, informam que, no final do século XVII, letrados de Salvador se reuniam nas tardes de sábado na Quinta do Tanque, propriedade onde os jesuítas aclimatavam plantas da Ásia e África, em certames de improvisação poética. Neles, usavam versos de medida velha e medida nova em romances, sonetos, oitavas, silvas, liras e improvisos de "mote e glosa," cujas rimas se adaptavam aos temas segundo os preceitos da verossimilhança e decoro dos gêneros das composições. Caso de rimas oxítonas e rimas em acha, echa, icha, ocha, ucha ou apa, epa, ipa, opa, upa, então cômicas. Os conceitos agudos efetuados com esses e outros procedimentos eram aplaudidos como signos de discrição. Os poemas eram copiados em manuscritos e imitados em variantes que eram copiadas a sua vez e assim por diante.

O estudo das didascálias permite constituir protocolos de leitura e formalizar os códigos prescritivos e metaprescritivos do contrato enunciativo dos poemas. No Códice Rabelo, são agrupados segundo os temas numa disposição evidenciada pelas didascálias. Os agrupamentos evidenciam princípios de ordenação que informam sobre as maneiras de definir autor e auctoritas no 
corpus atribuído a Gregório. Houaiss propôs fazer cópias de todos os poemas e distribuí-las entre pesquisadores brasileiros que, reunidos em equipes, tentariam estabelecer um "resíduo irredutível" atribuível com certeza ao autor Gregório de Matos. A presença do mesmo poema em pelo menos dois manuscritos diferentes parecia ser, para Houaiss, o primeiro critério de constituição de tal "resíduo irredutível." Moreira, deve-se notar, critica o fetichismo da origem implícito nessa abordagem, propondo que a configuração material dos códices é elemento definidor da autoria dos poemas. Segundo ele, é impossível afirmar que um "texto original" tenha existido como origem de uma tradição textual e que, em seguida, tenha sido deformado e adulterado por cópias sucessivas que afastaram os leitores mais e mais da verdade inicial, verdadeiro Ideal edênico, devendo ser consideradas, portanto, como corrompidas e não confiáveis.

A edição de Amado permite visualizar claramente a dispositio dos poemas no Códice Rabelo (Matos, Obras completas). Duas ordens distintas se superpõem nela. A primeira é cronológica e ordena os poemas segundo as etapas da vida de Gregório de Matos narrada na Vida: em Portugal (1648-1682 ou 1686), na Bahia (1682 ou 1686 até 1694), em Angola (1694 e 1695) e em Recife (1695-1696). A segunda é de ordem retórico-poética, dispondo os poemas segundo a hierarquia dos gêneros vigente no século XVII: inicialmente, a poesia lírica (a lírica sacra antes, depois a amorosa); em seguida, a poesia cômica (poemas jocosos do subgênero ridículo, seguidos de textos satíricos do subgênero maledicência; finalmente, poemas fesceninos, de obscenidade escatológica). Também não se negligencia, nesta ordem, uma hierarquia das formas poéticas: primeiramente, as italianas, que utilizam a medida nova, o verso decassílabo; depois, formas mais populares ou mais antigas, como os romances de medida velha, com versos pentassílabos e heptassílabos, e, entre elas, as oitavas, as décimas, as silvas ou composições pastorais de métrica alternada. É de assinalar que as edições impressas a partir do século XIX negligenciam sistematicamente as duas ordens da disposição dos poemas. Seus autores fazem seleções que isolam os poemas como obras autônomas, não considerando que o contexto discursivo do códice fornece sentido a cada um deles como elementos de um conjunto dialógico ou polílogo intertextual que reproduz a movência dos processos da sua invenção e circulação que só existe em suas variações. 
Nos manuscritos, a função autor é o ponto de convergência das versões dos poemas que realizam a auctoritas deles como adequação à auctoritas do gênero poético de que eles eram, para o juízo de quem os juntou no mesmo códice, outras realizações emulatórias. Logo, nos manuscritos, a auctoritas não significa a realidade da psicologia individual de um homem que tem a posse e a propriedade do poema, mas é dispositivo discursivo produzido pela aplicação de esquemas retóricos pressupostos por sua recepção contemporânea, ao menos pela sua recepção letrada. Seus ouvintes-leitores valorizavam o artifício com que os preceitos do dispositivo eram aplicados, ao mesmo tempo que julgavam a novidade da significação dos poemas feitos como emulação de uma ou mais auctoritates. Assim, a disposição dos poemas no códice constitui o nome "Gregório de Matos e Guerra" como dispositivo de designação de uma auctoritas lírica, sacra e erótica, e de uma auctoritas cômica, ridícula e maledicente. A função autor classifica gêneros poéticos, antes de ser confirmação da origem individual das obras. Dessa perspectiva, Rabelo pôde coletar textos de origens diferentes, como paródias que estudantes de Coimbra faziam de textos de Camões e poemas de outros poetas portugueses e espanhóis, atribuindo-os a Gregório. Para Rabelo, Gregório de Matos é o nome da autoridade de um ou mais gêneros, mais que o nome de um autor empírico. Reunindo todos os poemas que achou sob a etiqueta Gregório de Matos e Guerra, constitui uma autoridade lírica e uma autoridade cômica. Foi reprovado por ter-se equivocado quanto à origem dos textos. A reprovação não procede, pois ele não obedecia aos critérios românticos de origem, genuinidade e originalidade.

Para Rabelo, a auctoritas associava-se à noção latina de fides, a boa fé que deve presidir às convenções públicas dos povos e às transações privadas de indivíduos, como propõe Cícero (25). Quintiliano a pressupõe na Instituição oratória, quando escreve sobre a elegia erótica de Ovídio, distinguindo-a da elegia de Tibulo, Galo e outros poetas romanos por meio da maneira como compõem os estilos da elocução. Tibulo é puro e elegante, Ovídio mais lascivo, Galo mais severo e Catulo, culto (52). Todos aplicam os mesmos lugares-comuns, o mesmo tipo de verso, as mesmas situações dramáticas e narrativas da elegia erótica; todos compõem o poema como enunciação fictícia de um pronome pessoal, ego, que figura a persona do amante desprezado por mulher volúvel. É o 
ego não substancial de um tipo poético, que emula poetas gregos e alexandrinos, enquanto recompõe, em cada poema, a diç̧ão que faz a adequação de seu estilo aos lugares-comuns prescritos no gênero para inventar e ornar a voz particular de seu éthos movido por páthe eróticos. O estilo não é o homem, mas o destinatário, ou seja, a forma poética feita como variação dos preceitos do gênero elegíaco que é comunicada ao destinatário como uma audição ou um modo particular de ouvir o verso elegíaco de um auctor. $\mathrm{O}$ ato com que inventa o poema não é apenas mimético, como imitação verossímil de discursos sobre o corpo, o amor e o sexo tidos por relevantes no presente romano dos poetas, mas também valorativo, constituindo no estilo a posição adequada da recepção do destinatário. Os poetas inventam imagens como variações elocutivas das normas que regulam os discursos sobre o amor na vida romana; com isso, imitam endoxa ou opiniões sobre ele tidas por verdadeiras no campo semântico do seu tempo para debatê-las na cena dos poemas como conflitos de amor.

Simultaneamente, sua enunciação faz referência ao seu próprio ato, encenando, no estilo, a posição na qual o destinatário deve receber as imagens, entendendo-as duplamente como comunicação da experiência coletiva dos preceitos técnicos e comunicação da variação elocutiva particular. Os públicos romanos cultos eram capazes de refazer a ordenação retórica do fingimento poético que modela as pessoas discursivas da elegia erótica como tipos da etopeia, retrato epidítico do caráter. Conheciam os preceitos do gênero e sabiam que os tipos habitam um nome próprio que faz de seu artifício um ser fictício. Na comunicação fictícia, o ego desse ser fala com total sinceridade estilística. A diferença entre os elegíacos Tibulo, Catulo, Galo, Ovídio, Propércio etc. decorria da fides elegíaca particular de cada um deles, efetuada como aplicação diferencial dos tropos da elocução aos mesmos lugares-comuns. O público culto sabia disso, dizendo Ovidius lascivus, para significar um estilo particular do gênero elegia erótica exercitado pelo poeta Ovídio, não a psicologia do homem Publius Ovidius Naso.

Como os latinos, o autor ou autores dos poemas do Códice Rabelo sabiam que as paixões são naturais; e que, quando são poéticas ou fictícias, não são naturais e informais, mas afetos artificialmente inventados para efetuar a fides, a credibilidade verossímil e decorosa. Rabelo não ignorava que muitos poemas do seu códice não eram do poeta Gregório de Matos e Guerra; mas necessitava deles em 
sua taxonomia e conservou o nome para designar o conjunto, porque o nome tinha a fides que para públicos contemporâneos representava a excelência dos gêneros que o códice ilustra. Assim, o conceito de autor do códice pressupõe e implica o conceito de obra como realização particular que emula retoricamente a auctoritas dos gêneros dos poemas, e o de público, como sinônimo discreto do autor.

A dispositio dos poemas era evidente como protocolo de leitura para públicos contemporâneos discretos que asseguravam a recepção das auctoritates emuladas neles. A auctoritas é dispositivo de representação, ou seja, dispositivo retórico de produção da presença de posições hierárquicas de fides regradas pela teologia-política ibérica do pactum subjectionis que devem ser adequadamente reproduzidas pelo destinatário. Por outras palavras, a auctoritas é elemento essencial da produção e regulação dos discursos do corpo místico da Bahia. No século XVII, sua doutrina era difundida no trivium e quadrivium da educação jesuítica-por exemplo, com a definição de pessoa feita por Inácio de Loyola nos Exercícios espirituais como unidade das três faculdades da alma, memória, vontade, inteligência, ou dos três níveis constitutivos do homem, animal, ser racional, imagem de Deus. No ato da inventio, o poeta tinha a memória das auctoritates dos gêneros, recorrendo a lugares-comuns deles e à erudição, como Gracián propõe no último capítulo de El discreto. A inteligência lhe permitia percorrer os assuntos poéticos da memória, estabelecendo analogias de atribuição e proporção entre suas partes segundo a doutrina do engenho, que fundia perspicácia dialética e versatilidade retórica nos estilos das agudezas. Finalmente, a vontade, como faculdade afetiva, permitia exercitar a conformatio da mente com as imagens agudas que figuravam o momento extático da iluminação dela pela luz da Graça inata. Como foi dito, esses critérios retórico-poéticos e teológico-políticos constituem dois tipos intelectuais de destinatários, o discreto e o vulgar. O discreto-que se distingue pela capacidade de fazer distinções-é tipo erudito, conhecedor das artes da memória que lhe permitem reconhecer todos os lugares-comuns aplicados pelo autor e testemunhar a força do sistema de regras, reconhecendo-as como equivalentes diretos ou sinônimos da auctoritas. Segundo Inácio de Loyola, discretio não é diferente de caritas, pois é a capacidade de efetuar juízos justos e prudentes. O próprio Rabelo é discreto e coleta poemas e escreve para leitores que são como ele. $\mathrm{O}$ vulgar-o que não tem 
juízo-é definido negativamente pelos manuscritos como tipo incapaz de ler os poemas segundo a ordem da invenção e disposição deles, pois não sabe fazer as distinções dos preceitos aplicados. Isso não significa que seja insensível à poesia. Pode ser e é afetado por ela, reagindo a seus efeitos, mas não compreende o artifício das regras que presidiram sua invenção.

Assim, as variantes transcritas nos manuscritos não decorrem de os poemas terem sido deformados em cópias sucessivas ou de não terem sido memorizados da mesma maneira quando foram transmitidos por testemunhos diferentes. De modo mais fundamental, decorrem do tratamento dos temas. No caso, são os diferentes tipos de auctoritas e de fides que estão em jogo, pois um mesmo tema pode ser e é tratado segundo os preceitos da auctoritas própria de cada gênero. O tema do rosto da dama, por exemplo, costuma ser tratado num soneto lírico com descrições agudas; o do seu corpo pode ser composto no mesmo gênero com a linguagem da cortesia. No gênero satírico, os mesmos temas são figurados com imagens obscenas, como ocorre em dois sonetos dedicados a Caterina.

Soneto 1

Vês esse Sol de luzes coroado?

Em pérolas a Aurora convertida?

Vês a Lua de estrelas guarnecida?

Vês o Céu de Planetas adorado?

O Céu deixemos; vês naquele prado

A Rosa com razão desvanecida?

A Açucena por alva presumida?

O Cravo por galã lisonjeado?

Deixa o prado; vem cá, minha adorada, Vês de esse mar a esfera cristalina

Em sucessivo aljôfar desatada?

Parece aos olhos ser de prata fina?

Vês tudo isto bem? Pois tudo é nada

À vista do teu rosto, Caterina.

\section{Soneto 2}

Rubi, concha de perlas peregrina,

Animado cristal, viva escarlata,

Duas safiras sobre lisa prata,

Ouro encrespado sobre prata fina.

Este o rostinho é de Caterina;

E porque docemente obriga, e mata, Não livra o ser divina em ser ingrata, E raio a raio os corações fulmina.

Viu Fábio uma tarde transportado Bebendo admirações, e galhardias, A quem já tanto amor levantou aras:

Disse igualmente amante, e magoado: Ah muchacha gentil, que tal serias, Se sendo tão formosa não cagaras! 
O primeiro é lírico, com tópicas e léxico petrarquistas do amor da donna angelicata; o segundo, explicado pela didascália como "Desaires da Formosura com Pensões da Natureza Ponderadas na Mesma Dama," é lírico até o último termo do último verso, em que o decoro e a verossimilhança mudam com o uso inesperado de termo inconveniente, a indecência "cagaras." O poema joga com a encenação de duas autoridades ou de dois regimes de invenção e ordenação discursivas: o leitor lê um texto lírico até o último termo, que altera comicamente o regime lírico, degradando-o na obscenidade baixa. Essas mudanças de registro pressupõem a discrição do destinatário e do leitor, capazes de articular simultaneamente os dois regimes de auctoritas para definir a verossimilhança e o decoro específicos de suas diferentes fides e os efeitos cômicos decorrentes da alteração delas.

Logo, cada tema tratado com diferentes graus de decoro e verossimilhança pode dar lugar a efeitos de significação e sentido diferentes para diferentes recepções. As variantes, como as que trocam o termo "zorra" por "porra" em sonetos satíricos dos Caramurus da Bahia, não são defeitos ou erros de cópias de originais que deveriam ser restabelecidos. Nos manuscritos, são efetivamente variações elocutivas contemporâneas, fazendo parte do dispositivo autoral bastante complexo usado por Rabelo. Pensar as variantes romanticamente em termos de genealogia individual, genuína e original da obra, é um falso problema. A variação faz parte do produto poético designado pelo nome de Gregório de Matos e Guerra como jogo com diferentes tipos de auctoritas, estilos, decoros, verossímeis, fides e, portanto, de diferentes destinatários.

No Códice Rabelo, os poemas ridículos emulam a sátira de Horácio e compõem o personagem satírico como tipo urbano, que faz dos pecados alheios ocasião para a ironia amável e desdenhosa. Os poemas maledicentes emulam Juvenal, compondo o personagem satírico como bufão encolerizado que vitupera a corrupção com sarcasmo e obscenidade. Os dois subgêneros fornecem ao personagem satírico várias possibilidades de ação. Segundo uma convenção peripatética, ele é o vir bonus dicendi da oratória romana, homem honesto perito em falar que, indignado com a corrupção da sua pátria, age para restabelecer a ordem. Sua arma é sua capacidade de produzir retoricamente a afetação de indignação. Segundo a convenção estoica, como a que Sêneca expõe em De ira, 
a mesma indignação é in-digna, porque irracional como os vícios vituperados. Segundo a auctoritas de Juvenal, a sátira é expressão desordenada da cólera do satírico, adequada à sua sociedade caótica. Em todos os casos, o artifício é o de inventar a fides que faz crer que a sátira é "natural," sem regras.

Nos poemas do Códice Rabelo, a matéria geral do gênero cômico é a feiura, que é física, feiura do corpo, e moral, feiura da alma. A feiura física corresponde a incontáveis espécies de deformações e misturas corporais; a feiura da alma divide-se em duas espécies, feiura da estupidez e feiura da maldade. Como se sabe, nas letras e artes antigas, a figuração da feiura física metaforizava a feiura moral. Na Poética de Aristóteles, acha-se uma nota sobre o cômico e o feio: "A comédia é a imitação de homens de qualidade moral inferior, não em toda espécie de vício, mas no domínio do ridículo, que é uma parte do feio. Porque o ridículo é uma feiura sem dor nem dano; assim, por exemplo, a máscara cômica é feia e disforme sem expressão de dor" (1459).

Aristóteles refere a matéria geral do cômico, o aiskhrón, o turpe latino ou o feio, propondo que tem duas espécies, o cômico inofensivo, que não causa dor, e o cômico nocivo, causa de dor. No trecho, a máscara teatral sintetiza a deformação inofensiva tratada por um subgênero cômico, ghéloion, que a latinidade e os autores dos séculos XVI-XVIII chamaram de ridiculum, o pequeno riso. Por oposição, há outras espécies de deformações nocivas, que causam dor e horror, sendo tratadas como maledicentia. A definição do cômico como deformação pressupõe a convenção grega e latina do belo-bom (kalós-agathós, pulchrum-honestum) como unidade racional sem mistura e sem desproporção. O feio-mau (kakós-turpe) deforma a medida racional do bom-belo. Sensivelmente, a deformidade é feia; moralmente, viciosa e, intelectualmente, errada.

Aristotelicamente, a virtude do bom-belo é a unidade racionalmente situada entre dois extremos excessivos. A coragem é virtude; um dos extremos dela é a temeridade, como excesso para mais; outro é a covardia, como falta ou excesso para menos. Ambas são extremos ou vícios, com a diferença de que a temeridade é excesso forte, e a covardia, falta fraca de virtude. Aristotelicamente, a comédia trata dos extremos caracterizados pela falta de virtude que os faz vícios não nocivos que causam riso. Latinamente, os vícios fortes são objeto da satura maledicente. No "Trattato de' ridicoli," de Il cannocchiale aristotélico, 
Tesauro amplifica Aristóteles e os latinos, fornecendo receitas para produzir deformações e misturas ridículas na comédia e deformações e misturas agressivas na sátira.

Para efetuar as deformações e misturas descritas por Tesauro, os poemas cômicos do Códice Rabelo recorrem a três procedimentos. As didascálias as chamam de "anatomia horrorosa." O mais usual figura o tipo satirizado como ser misto, feito de pedaços de campos semânticos disparatados. O efeito é o monstro incongruente. Outro procedimento amplifica partes do corpo satirizado, como o nariz do governador Câmara Coutinho, que chega à praça duas horas antes que seu corpo. $\mathrm{O}$ terceiro recorre à obscenidade, que confere vida própria a partes do corpo, como o nariz dotado de vontade autônoma que se põe de cócoras no meio da cara do satirizado e defeca.

As três técnicas constituem e vituperam tipos corruptos de todas as ordens sociais da Bahia; simultaneamente, a enunciação interpreta a vituperação como teatro sacro do qual o personagem satírico é o cenógrafo. Na cena, os lugares-comuns do gênero demonstrativo são aplicados como argumentos genéricos particularizados com a paráfrase, a estilização e a paródia de referências locais. As didascálias indicam que os tipos satirizados são constituídos por meio dos 11 lugares latinos de pessoa-aspecto físico, nome, sexo, idade, origem, língua, pátria, nação, fortuna, condição, educação-, evidenciando que o autor ou autores transformaram a generalidade que é o lugar-comum em mensagens específicas de situações particulares que diferenciam o poema da autoridade emulada. É fácil equivocar-se como um vulgar censurado na sátira quando os poemas cômicos são lidos da mesma maneira como se lê um texto moderno impresso. Lidos por muitos críticos brasileiros da perspectiva de critérios românticos que não mais pressupõem a normatividade retórica, parecem rascunhos grosseiros. Lendo-os como textos manuscritos do século XVII, evidencia-se que seu autor lhes aplicou o preceito horaciano do ut pictura poesis, pressupondo a definição católica do conceito como metáfora artificiosa realizada na mente quando o juízo é iluminado pela luz natural da Graça. Neles, as imagens são efetuadas como disegno interno, desenho interno, como o define Federico Zuccari, segno de Dio, signo do desígnio de Deus. Quando o conceito é figurado na matéria verbal, no desenho do verso se ouve ou lê o desígnio 
divino que aconselhou o juízo do poeta a achar relações inesperadas entre coisas, conceitos e signos. O ut pictura poesis é, assim, um dos principais procedimentos técnicos que ordenam a verossimilhança e o decoro dos estilos líricos e cômicos dos poemas feitos segundo a concepção metafísica do desenho interno.

É útil lembrar que a comparação feita por Horácio, ut, "como", propõe a homologia dos procedimentos retóricos que ordenam mimeticamente os efeitos de estilo da pintura e da poesia, não a identidade das substâncias da figuração pictórica e verbal: "Ut pictura poesis; erit quae, si propius stes, te capiat magis, et quaedam, si longius abstes; haec amat obscurum, volet haec sub luce videri, iudicis argutum quae non formidat acumen; haec placuit semel, haec deciens repetita placebit”; 'Como a pintura é a poesia: haverá uma que, se estás mais perto, mais te seduz, e outra, se estás mais afastado; uma ama o obscuro; outra, que não teme a sutileza aguda de um juiz, quererá ser contemplada à luz; uma agradou uma só vez, outra agradará repetidas vezes' (70). Há um modo próprio de composição do estilo para cada obra segundo sua destinação e sua apreciação, ou seja, o ut pictura poesis também é doutrina genérica da verossimilhança necessária para que a obra possa cumprir mimeticamente as três funções retóricas, docere, delectare, e movere. Wesley Trimpi propôs que os versos podem ser distribuídos em três pares de oposições: 1) distância: em termos de perto/longe (si propius stes/ si longius abstes); 2) claridade: em termos de clarezal obscuridade (obscurum/sub luce); e 3) número: em termos de uma vez/várias vezes (semel/repetita) (30). Se a categoria distância parece referir-se ao movere, evidenciado pelo verbo de pathos (te capiat magis), a categoria claridade implica o docere, que figura a avaliação do juízo (iudicis argutum quae non formidat acumen) enquanto a categoria número articula o delectare, legível no verbo que indica afeto agradável (placuit; placebit). As categorias delineiam, portanto, a generalidade das funções retóricas. As três oposições são operadores diferenciais da generalidade do aptum retórico e poético, funcionando como critérios de adequações estilísticas das partes da obra ao todo, como decoro interno, e de adequação da obra à circunstância da recepção, como decoro externo.

No Códice Rabelo, as imagens dos tipos viciosos pintados como mistos incongruentes são inconveniências fantásticas e inverossímeis, tornando-se convenientes ou icásticas e verossímeis para figurar a não unidade do vício, o que 
ocorre quando são observadas de um ponto fixo que, nas letras do século XVII, é calculado como a unidade virtuosa da prudência, que inclui motivos éticos, teológicos e políticos da racionalidade de Corte ibérica. Muitos poemas inventam os corpos dos tipos satirizados como ocorre pictoricamente nas misturas dos grylloi de Bosch e dos caprichos ou hieróglifos de telas de Valdés Leal: fazem um esboço rápido e grosseiro, sem preocupação com minúcias de desenho feito à ponta de pluma ou pincel, modelando-o como se utilizassem carvão grosso ou brocha, empastando as cores e as linhas como borrão ou caricatura esquemática. Aplicando a técnica do retrato dos progymnásmata de Aftônio e Hermógenes, retomada no século XII por Geoffroy de Vinsauf em Poetria Nova, figuram o corpo satirizado segundo um eixo vertical imaginário, dividido em sete partes, da cabeça aos pés. Quando vistas de perto pelas lentes de outros gêneros, como o lírico, as imagens que preenchem as sete secções parecem malfeitas e borradas; mas, sendo compostas como discurso para ser recebido à distância, "de longe," devido ao esquematismo dos traços, evidenciam-se adequadas ao tempo curto da recepção na praça pública que, no caso dos gêneros baixos, não perde tempo com minúcias, nem quer conceituações elaboradas. Diferentemente do que diz a crítica brasileira que recorre a categorias românticas psicologistas que desconhecem o ut pictura poesis, os poemas satíricos realizam com perfeição o preceito retórico do seu gênero, compondo a posição do destinatário como recepção "de longe," clareza de esboço obsceno e uma só vez. Neles, o efeito de mau acabamento é programático, ou seja, resulta de uma técnica refinada de produção de inacabamento. A sátira é gênero público, por isso calcula exatamente, no estilo, a distância entre seus efeitos de desproporção e a recepção. A distância é articulada no estilo, pois a sátira é arte cenográfica. Ela é para a poesia o que a caricatura é para o desenho. Se for trabalhada como um soneto lírico, a elocução acumulada de ornatos a faz hermética, impedindo que seja dita em voz alta uma única vez. Perde a força do impacto se é repetida; logo, quanto mais "grosseira" é, melhor funciona. Obviamente, sua grosseria é discreta, porque calculadamente conveniente à sua recepção oral.

Vejam-se dois exemplos, o primeiro de Gregório de Matos e o segundo do peruano Juan del Valle y Caviedes, em que a persona satírica se enuncia como pintor retratista. Cada secção do corpo esboçado segundo o eixo vertical é preenchida pelas deformações e misturas: 
1.

Vá de retrato

por consoantes,

que eu sou Timantes

de um nariz de tucano

pés de pato.

Pelo cabelo

começo a obra,

que o tempo sobra

para pintar a giba

do camelo. (219)
2.

Segundo pincel, la pluma

pintar pretende la idea

con tinta, un original

a quien la tinta le adecua.

En blanco quiero dejar

sus perfecciones, si aquéstas

dan en el blanco, dejando

embebidas todas ellas.

Su pelo me está brindando

a la pintura y lo hiciera,

pero el pelo su pellejo

lo tiene adentro y no afuera. (259)

O ut pictura poesis também ordena poemas em que a persona satírica compõe interlocutores discretos e vulgares, afirmando que não utilizará o estilo agudo de gongóricos, que compõem para mentes cortesãs, pois será vulgar ou obscena, falando claramente para todos. No caso, a obscenidade da "Musa praguejadora" é retoricamente decorosa, pois é óbvia, não necessitando de interpretação, o que a faz própria para ser entendida por destinatários vulgares na primeira vez em que é ouvida na praça:

\footnotetext{
Cansado de vos pregar

cultíssimas profecias

quero das culteranias

hoje o hábito enforcar:

de que serve arrebentar

por quem de mim não tem mágoa?

Verdades direi como água

porque todos entendais

os ladinos, e os boçais,

a Musa praguejadora.

Entendeis-me agora? (472)
} 
Para terminar: na Bahia do século XVII, a prática de confeccionar manuscritos e as diversas espécies de troca deles funcionavam objetivamente como processos de reprodução das redes corporativas do todo social objetivo da Bahia, que pressupunham o estado da paz social alegado pelas instituições portuguesas como condição de sua existência. Os textos manuscritos eram dispositivos simbólicos de conferir e negar representação, bastando lembrar que muitos públicos empíricos eram incapazes de escrevê-los e lê-los e, quando os ouviam, também incapazes de reconhecer os preceitos e as técnicas que os produziam, sendo por isso classificados como vulgares.

\section{Notas}

1 No cofre 50 da Seção de Manuscritos da Biblioteca Nacional, o códice 63, com letra do século XVII, 535 fls., com o título Poesias, contém produções variadas, como "Fábula jocosa;" "Os amantes de Espanha;" "Amores de Píramo e Tisbe;" "O roubo de Prosérpina-O ladrão velhacão e a gulosa dos bagos;" "Fábula de Caco e Hércules;" "Jornada-que o senhor Francisco de Brito e Meneses, reitor da Universidade de Coimbra, foi com a sua gente em socorro à vila de Buarcos, estando quase assaltada dos holandeses. Descrevem-se os amores da Ninfa Coimbra, que deu nome à cidade, e a origem de suas armas;" "Concílio dos bêbados, poema macarrônico, paródia d'Os Lusíadas, pelo dr. Manoel do Valle, deputado do Santo Ofício de Évora." Deste último, veja-se a primeira oitava: "As armas e os borrachos assinalados, / que de Alcochete, junto a vila Franca, / por vinhos nunca dantes navegados / passaram muito além da Peramanca: / Em pagodes, e ceias esforçados / mais do que se permite à gente branca, / em Évora cidade se alojaram / Onde Pipas, e Quartos, despejaram." Seguem mais 105 estrofes. Após esta paródia, segue: "El cortesano español, político, y moral; documento de un padre, a su hijo que se iba a vivir en la Corte," etc.

2 Foi comum nesse tempo o tipo da freira poeta, como Violante do Céu, e a correspondência trocada entre as ordens religiosas, que propunham motes a serem glosados em certames poéticos. Em 1689, quando Sor Juana Inés de la Cruz publicou Inundación castálida, as freiras portuguesas lhe solicitaram que escrevesse algo para elas, o que a mexicana logo fez, enviando-lhes um conjunto de vinte enigmas trovados. Os poemas chegaram a Lisboa em 1693 e, no ano seguinte, foram copiados em todos os conventos da cidade, tornando-se matéria para emulações e interpretações poéticas da Casa do Prazer, uma associação ou academia de freiras letradas.

3 Contra Lutero, Calvino, Maquiavel e o rei James I de Inglaterra, o jesuíta Francisco Suárez sistematizou a doutrina católica do poder em dois tratados: De legibus ac Deo legislatore (1612) e Defensio fidei catholicae et apostolicae adversus anglicanae sectae errores (1613). Tomemos, como exemplo, o parágrafo seguinte: "Mas a liberdade cristã não consiste na isenção das leis humanas justas, nem na isenção da coação legítima ou do justo castigo dos crimes que se cometem contra a paz e a justiça; senão que consiste na isenção da lei mosaica ou do temor servil, ou (o que é igual) consiste em uma submissão voluntária, baseada na idea cristã do amor e da caridade, a qual não apenas não contradiz o poder do estado, mas antes o apoia, quando existe. E quando não existe, supre sua falta com por coação" (Suárez, Defensio fidei 60). 
4 Na sociedade luso-brasileira do século XVII, a identidade da pessoa é definida como representação-uma forma específica da posição social—e pela representação-uma ocasião de aplicação da forma como aparência decorosa subordinada no corpo místico do império português. Por "representação," no caso, entendem-se quatro coisas: 1) o uso particular, em situação, de signos que tornam presente outra coisa ausente; nas representações luso-brasileiras do século XVII, os signos são recortados em uma matéria como imagens de conceitos produzidos na substância espiritual da alma participada pela substância metafísica de Deus; 2) a aparência ou a presença da coisa ausente na forma produzida na substituição; 3) a formalização retórico-poética da forma da presença da ausência; e 4) a posição hierárquica encenada na forma como tensão e conflito de representações. Sobre "representação," veja-se Marin, Des pouvoirs; De la représentation.

5 Como "centelha da consciência," a sindérese é a presença da Lei natural na mente, aconselhando o bem e vituperando o mal. No XVII, a noção relaciona-se com a doutrina do juízo e da prudência, fundamentando a solércia ou a sagacidade que especifica o tipo do discreto; é também a sindérese que evidencia, na forma exterior do decoro estilístico, as operações éticas do juízo, como circumscriptio. Cf. Santo Tomás de Aquino I-II, 94, i, ad. 2; I, 79, xii.

\section{Obras citadas}

Andrade, Oswald de. "Manifesto antropófago." Revista de Antropofagia 1.1 (1928): 3, 7. Print. Araripe Júnior, Tristão de Alencar. Gregório de Matos. Rio de Janeiro: Fauchon, 1894. Print.

Aristóteles. "De poetica." The Basic Works of Aristotle. Trad. Ingram Bywater. New York: Random House, 1941. 1455-87. Print.

Barbosa, Cônego Januário da Cunha. "Biografia dos brasileiros distinctos por lettras, armas, virtudes, etc." Revista Trimensal de História e Geographia ou Jornal do Instituto Histórico e Geográphico Brasileiro 3.9 (1841): 333-37. Print.

Burke, Peter. "Lart de l'insulte en Italie aux XVIe et XVIIe siècles." Injures et blasphèmes. Ed. Jean Delumeau. Paris: Imago, 1989. 49-62. Print.

Campos, Haroldo de. O seqüestro do barroco na formação da literatura brasileira: o caso Gregório de Matos. Salvador da Bahia: Fundação Casa de Jorge Amado, 1989. Print.

Candido, Antonio. Formação da literatura brasileira. 2 vols. São Paulo: Martins, 1959. Print.

Caviedes, Juan del Valle y. Obra completa. Ed. Daniel R. Reedy. Caracas: Ayacucho, 1984. Print. Chartier, Roger. Les origines culturelles de la révolution française. Paris, Seuil, 1990. Print.

Cícero. On Duties (De officiis). Trad. Walter Miller. Cambridge, MA: Harvard UP, 1913. Print.

Cunha, Euclides da. "Carta a Araripe Júnior." Obra Completa. 2 vols. Ed. Afrânio Peixoto. Rio de Janeiro: Aguilar, 1966. 2: 625-27. Print.

Geoffrey de Vinsauf. Poetria Nova of Geoffrey of Vinsauf. Trad. Margaret F. Nims. Toronto: PIMS, 1967. Print.

Gracián, Baltasar. El discreto. Ed. Aurora Egido. Madrid: Alianza, 1997. Print.

Houaiss, Antônio. “Tradição e problematicidade de Gregório de Matos." Obras completas de Gregório de Matos e Guerra. 7 vols. Ed. James Amado. Salvador: Janaína, 1968. Print.

Inácio de Loyola, Santo. Exercícios espirituais de Santo Inácio. São Paulo: Loyola, 2002. Print.

Juana Inés de La Cruz, Sor. Enigmas ofrecidos a la Casa del Placer. Ed. Antonio Alatorre. México D.F.: Colegio de Mexico, 1994. Print. 
Júlio de Albuquerque Lima, Sílvio. Reaçõis na literatura brasileira. Rio de Janeiro: Antunes, 1938. Print.

Marin, Louis. De la représentation. Paris: Gallimard, 1994. Print.

—. Des pouvoirs de l'image: gloses. Paris: Seuil, 1993. Print.

Matos, Gregório de. Obras completas de Gregório de Matos e Guerra. Ed. James Amado. 7 vols. Salvador: Janaína, 1968. Print.

Merlin, Hélène. Public et littérature en France au XVIIe siècle. Paris: Les Belles Lettres, 1994. Print.

Moreira, Marcello. Critica textualis in caelum revocata? Uma proposta de edição e estudo da tradição de Gregório de Matos e Guerra. São Paulo: U de São Paulo, 2011. Print.

Peixoto, Afrânio, ed. Gregório de Matos: Obras. 6 vols. Rio de Janeiro: Academia Brasileira de Letras, 1923-1933. Print.

Pound, Ezra. Make it New. London: Faber and Faber, 1934. Print

Quintiliano. Institutio oratoria. Trad. H.E. Butler. Cambridge, MA: Harvard UP, 1980. Print.

Rabelo, Manuel Pereira. "Vida do excelente poeta lírico, o doutor Gregório de Matos e Guerra." Obras completas de Gregório de Matos e Guerra: Crônica do viver baiano seiscentista. 7 vols. Ed. James Amado. Salvador da Bahia: Janaína, 1969. 7: 1689-721. Print.

Rio de Janeiro, Biblioteca Nacional, Seção de Manuscritos, Cofre 50, 63.

Senado da Câmara, Cidade de Salvador da Bahia. Atas da Câmara: 1625-1700. 6 vols. Salvador: Diretoria do Arquivo e Divulgação da Prefeitura Municipal do Salvador, 1944-51. Print. Cartas do Senado: 1638-1710. 5 vols. Salvador: Diretoria do Arquivo e Divulgação da Prefeitura Municipal do Salvador, 1950-62. Print.

Séneca. Moral Essays: De providentia, De constantia, De ira, De clementia. Trad. John W. Basore. Cambridge, MA: Harvard UP, 1979. Print.

Spina, Segismundo, ed. Gregório de Matos. São Paulo: Assunção, 1946. Print.

Suárez, Francisco. Defensio fidei III: Principatus politicus o la soberanía popular. Ed. e trad. Eleuterio Elorduy e Luciano Pereña Vicente. Madrid: CSIC, 1965. Print.

- Selections from Three Works of Francisco Suárez: De legibus ac Deo legislatore (1612), Defensio fidei catholicae et apostolicae adversus anglicanae sectae errores (1613), De triplici virtute theologica, fide, spe et charitate (1621). 2 vols. Ed. e trad. Gladys L. Williams, Ammi Brown e John Waldron. Oxford: Clarendon, 1944. Print.

Romero, Sílvio. História da literatura brasileira. 5 vols. Rio de Janeiro e Brasília: José Olympio e Instituto Nacional do Livro, 1980. Print.

Tesauro, Emanuele. “Teorica de' ridicoli." Il Cannocchiale Aristotelico o sia, idea delle argutezze heroiche vulgarmente chiamate imprese. Turin: Sinibaldo, 1654. 645-57. Print.

Tomás de Aquino, Santo. The Summa Theologiae of Saint Thomas Aquinas. 10 vols. Scotts Valley, CA: NovAntiqua, 2008-. Print.

Trimpi, Wesley. "Horace’s Ut pictura poesis: The Argument for Stylistic Decorum." Traditio 34 (1978): 29-73. Print.

Varnhagen, Francisco Adolfo de. “Gregório de Mattos Guerra." Florilégio da poesia brazileira. 3 vols. Lisboa: Imprensa Nacional, 1850-53. 1: 20-105. Print.

Veloso, Caetano. “Triste Bahia." Transa. Polygram, 1972. LP.

Veríssimo, José. “ Gregório de Matos.” História da literatura brasileira: de Bento Teixeira (1601) a Machado de Assis (1908). Brasília: U de Brasília, 1963. n.p. Print. 
Zuccari, Federico. L'idea de'pittori, scultori et architetti, del cavalier Federico Zuccaro, divisa in due libri. Per A. Disserolio. In Torino, 1607.

Zumthor, Paul. Essai de poétique medievale. Paris: Seuil, 1972. Print.

João Adolfo Hansen é professor titular (aposentado) de Literatura Brasileira do Departamento de Letras Clássicas e Vernáculas na Universidade de São Paulo. Autor de livros e ensaios sobre as letras luso-brasileiras dos séculos XVI, XVII e XVIII e sobre autores brasileiros modernos, como Machado de Assis, Carlos Drummond de Andrade e João Guimarães Rosa. 